derte, gut belegte und kritische einführende Analyse des Kernbereichs der EG-Entwicklungshilfepolitik.

Marco Núñez-Müller

\title{
Bertrand Schneider
}

\section{Die Revolution der Barfüßigen}

Ein Bericht an den Club of Rome. Wien, München, Zürich: Europaverlag, 1986, 288 pp., DM 36,-

It is estimated that the world's population exceeded five billion in July of 1987. Droughts are reported from Ethiopia, floods from India; all over the so-called Third World children and adults suffer from diarrhoea caused by unclean water. The poor condition of the world's economy increases the pressures on the developing nations, many of which can hardly pay the interest, let alone their debts. The list of facts relating to the seriousness of the situation of the Third World is without end. Countless are the reports about measures and attempts to curb the effects of underdevelopment, but only few talk about efforts aiming at the roots of the problems.

Therefore, this is the time for a report on a worldwide grass roots movement: the phenomenon of a peaceful revolution in the villages. The Revolution of the Barefooted is a sam ple study on the work of non-governmental organizations (NGO) and its effects on the population and the regions concerned. The present edition is the German translation by Harry Bernard of the French original La révolution aux pieds nus. The author Bertrand Schneider is Secretary General of the Club of Rome, a union of scientists founded in 1968, which has since dealt with many of the most complex contemporary problems. This survey stands in the tradition of the Reports to the Club of Rome, each of which has turned the attention of the public and of the political heads towards new developments and added new thoughts and ideas to the scientific discussion. Just as the first Report, The Limits to Growth by Dennis Meadows et al., called for a re-orientation in economic and social thinking as well as in the prevailing concept of progress in 1972, Schneider now calls for a new direction for the developmental efforts and for an awareness of the need for courageous political decisions. These have to take into account the changing situation in the Third World. His résumé leaves no room for the pessimistic approaches to developmental aid, which threaten to question the reasonableness of any support at all. Moreover, Schneider draws very optimistic conclusions and sets new priorities for the aid granted.

The report begins with a critique of the approach towards development taken in the last twenty years, which can more adequately be characterized by the term industrialization. Huge sums of money were - and still are - invested in large projects providing only few incentives for the vast majority of the population. Yet, the detrimental effects on unex- 
plored ecosystems, the extinction of living resources and the destruction of ancient cultural and settlement structures affect everyone. The success on the export side was diminished by the world's serious economic situation. The disrespect for local and national structures and cultural values caused apathy, repugnance and even animosity among the people of the South instead of motivating and stimulating their efforts and abilities. Additional factors, such as desertification, drought, local military conflicts and also migration into the cities and emigration ("brain drain"), poor administration and even poorer distribution of resources were widely unknown or underestimated by western specialists. Whereas these factors have received much attention by the critics, their focussing on the mistakes of the past lets them oversee the sucessful work of small organizations outside of the urban centers.

Schneider, therefore, focusses his study on an analysis of 277 micro-projects of NGO's of the North and the South. The NGO's of the South mostly consist of organizations formed by farmers in the three southern continents coordinating independent non-governmental programs, which were initiated by the successful work of the NGO's of the North. The variety among the projects is great - in terms of their size, their structure, their goals as well as, of course, their importance and impact. One aspect all the NGO programs have in common is their integration into the life of the villages. However, the NGO's are not the only organizations working at the roots, but most of the other associations, religious groups and co-operatives have a much less formal and persistent structure. Their role is as difficult to assess within the scope of a study on NGO's as individual enthusiasm, and thus individuals and un-organized groups are not subject of Schneider's study, either.

One intention of the report is to evaluate the implications of the enterprises of the NGO's for the development of the villages and to answer to what extent incentives for own initiatives are given and how willingly responsibility is accepted over them. Another point is the question, whether new strategies can be developed in the light of the experiences drawn from the objects, the methods, and the results - economical, social and cultural - of the micro-projects. Last, but not least, the study helps to answer the question whether it is possible to apply these same techniques with regard to a whole of two billion farmers in the Third World.

Since the situations of the nations differ in various ways, Schneider hesitates to use the term developing countries, but prefers to refer to the countries of the Third World, thus including those in a critical condition of progressing poverty. He explains the character and scope of the factors of underdevelopment, the most eminent of which are the debts, continuous political instability, ecological mismanagement, growth of population, and cultural alienation. In the evaluation of the efforts to fight underdevelopment, priority is given to the projects, which start out with improving the basic needs, such as water, food, hygiene and health, thus concentrating on two aims: helping the nations to get out of the worst poverty and initiating independent projects by the people themselves according to their respective needs.

When reference is made to non-governmental organizations, Schneider uses the defini- 
tion given by the UN Economic and Social Council, i.e. the international organizations which have not been established by international treaty, which may be granted consultative status (Art. $71 \mathrm{UN}$-Charter). His reference to a sociological definition shows how difficult it is to give a positive definition of what a NGO is. Their number can hardly be estimated: In 1984, about 2.230 NGO's concentrated on development in the industrialized nations, the number of NGO's in the Third World can only be estimated at more than ten thousand.

More than extensively evaluating the effects of the governmental aid in developing countries, Schneider's report is not reluctant to criticize the mistakes the NGO's make. Be it the competition between different NGO's in the Third World, which hinders cooperation even where it is necessary to reach the best possible results, or the "misunderstanding " that independence from government influence in the Third World country does not mean that success could be possible against the consent of the authorities.

The most fundamental mistake, however, is insufficient knowledge, interest and patience to deal with the cultures affected. For example, one of the most widely spread - and superficial - notions about the cultural misery westerners have is the misconception of the status of women and their role especially in agriculture, family and financial matters. Whereas the necessity that aid must be adequate for the region concerned is not new, the willingness to listen to the people and to learn about their cultural traits, their philosophy, their way of life and communication, their heritage, roles, institutions and values, thus to respect their solutions and ideas is "underdeveloped ". It is, therefore, both fitting and very instructive to read the opinions of the barefooted which Schneider quotes to complete the image presented by the innumerous examples from existing projects. Their number does not only make the reading more lively, but also lengthy at times, however, it cannot be denied that patience is necessary in dealing with and understanding foreign perspectives.

The general principle that the sponsor decides is not only prevalent in the form of the denial of the existence of a title to developmental aid. Moreover, the conviction that the sponsor's own know-how is modern and resembles ultimate reason stands for the little knowledge about and the little esteem for solutions inherent in the local culture and thought. The NGO's which have continued their work independently after the foreign initiators have left virtually all resemble good examples of integration into the culture. The rapid growth and the solid foundation of these NGO's of the South support this assertion. Especially education may not be used to form a "modern Western culture", but has to find a basis in the thinking of the people. Although this may sound like a new approach, this inside perspective of cultural respect is nothing more than what the - extensively used - phrase of the solution starting at the root of the problem almost literally means. Contrary to fears in the North, founding measures and projects on the local culture does not lead to an attitude of autarky and eventually of isolationism among the people of the Third World. People who export excess products to other villages, other regions or even countries after their own demand is satisfied, will be more open to ideas of trade and communication in every sense than people in famine producing export crops. The aware- 
ness of this continuing need for an adequate infrastructure to eliminate the unilateral dependence of villages on certain markets proves that this new approach to development through local integrated non-governmental initiatives from the North and the South does not supersede larger governmental projects in general. However, such projects have to be subordinated and closely interwined with the grass roots programs, which do - as the report proves - qualify for large scale expansion in numbers.

No matter how much the NGO's may be criticized in details, the revolution set in motion by the NGO's of the North and the South deserves respect and attention - as long as it is still peaceful.

Of course, the implications of this report are not unlimited. Many of the findings regarding mistakes in the past have previously been subject to surveys. Some are even known to a wider public. Unquestionably, however, the work of the NGO's of the North and the South, their success and the attitude they formed are not generally known. Not all of the present developmental projects of the "First World" give rise to the assumption that they are the result of due consideration of all the controversial aspects which Schneider points out. Only seldom, the values and culture of the barefooted seem to be reflected, even more seldom, their experience seems to be accepted as know-how. Thus, although no new theory is added to those already existing, the reading of Schneider's critical and encouraging report can be highly recommended to everyone who deals with the situation of the Third World and also for an interested public.

Ulf Marzik

\section{Peter Hamacher}

Die Maxime audiatur et altera pars im Völkerrecht

Ein Beitrag zum internationalen Verfahrensrecht unter besonderer Berücksichtigung der Rechtsgutachten des (StIGH) IGH

Springer Verlag Wien, New York 1986

Osterreichische Zeitschrift für öffentliches Recht und Völkerrecht, Supplementum 7

In auffälligem Kontrast zu den innerstaatlichen Rechtsordnungen fristet die Maxime "audiatur et altera pars" in der völkerrechtlichen Diskussion von jeher ein Schattendasein, was daran liegen mag, daß hier der Bereich des Prozeßrechts schon immer eher schwach ausgeprägt war.

In der vorliegenden Arbeit, die als Dissertation unter der Betreuung von Ignaz Seidl-Hohenveldern an der Universität Köln entstand, geht der Verfasser Peter Hamacher der Frage nach, ob und inwieweit der genannte Grundsatz auch im Bereich des Völkerrechts Geltung beanspruchen kann.

Im ersten Teil der Arbeit befaßt sich der Autor zunächst mit der Problematik des rechtlichen Gehörs in der gutachtlichen Tätigkeit des IGH. Nach einigen einleitenden Aus- 